Layla Kumala Rizki, Indriyani Puluhulawa / Jurnal Rab Contruction Research 6 (2) (2021)

\begin{tabular}{l} 
RACIC 6 (2) (2021) \\
UNIVERSITAS \\
\hline ABDURRAB \\
http://jurnal.univrab.ac.id/index.php/racic
\end{tabular}

\title{
PERANCANGAN STRUKTUR ATAS JEMBATAN SUNGAI MESIM MENGGUNAKAN RANGKA BAJA BERDASARKAN SNI 1725:2016
}

\author{
Layla Kumala Rizki ${ }^{1}$ dan Indriyani Puluhulawa ${ }^{2}$ \\ Program Studi Teknik Perancangan Jalan Jembatan, Jurusan Teknik Sipil, Politeknik Negeri Bengkalis \\ JL. Bathin Alam, Desa Sungai Alam, Bengkalis \\ Telp. (0766) 24566 \\ Email : rizki.laylakumala99@gmail.com
}

\begin{abstract}
Info Artikel
Abstrak

Sejarah Artikel:

Salah satu sungai yang terdapat di Pulau Rupat adalah Sungai Mesim dengan lebar $50,9 \mathrm{~m}$. Jembatan yang melintasi Sungai Mesim terbuat dari beton bertulang. Merujuk pada peraturan Bina Marga tahun 2015 untuk rintangan sepanjang 40

Diterima : Oktober 2021

Disetujui : Desember 2021

Dipublikasikan : Des 2021 hingga $200 \mathrm{~m}$ maka jenis jembatan rangka baja merupakan jenis yang ekonomis. Tujuan penelitian ini adalah untuk merencanakan ulang struktur atas Jembatan Sungai Mesim dan memperoleh dimensi struktur atas yang efektif. Perencanaan ini mengacu kepada SNI 1725:2016 tentang pembebanan jembatan, RSNI T-03-2005 tentang perencanaan struktur baja untuk jembatan, dan SNI T-12-2004 tentang perencanaan struktur beton. Jembatan Sungai Mesim direncanakan dengan panjang $52 \mathrm{~m}$ dalam 1 bentang, lebar $7 \mathrm{~m}$ dan tinggi rangka 6,45 m. Berdasarkan hasil

Keywords: perencanaan digunakan tipe rangka warren truss, tebal slab jembatan $200 \mathrm{~mm}$, gelagar memanjang menggunakan IWF 350.175.7.11, gelagar melintang

Struktur atas, rangka baja, jembatan menggunakan IWF 700.300.13.24, rangka utama menggunakan IWF 400.400.13.21 dan ikatan angin menggunakan IWF 150.150.7.10.
\end{abstract}

Kata Kunci: Struktur atas, rangka baja, jembatan

\begin{abstract}
One of the rivers on Rupat Island is the Mesim River with a width is $52 \mathrm{~m}$. The bridge that crosses the Mesim River is made of reinforced concrete. By following Marga 2015 regulations for 40 until $200 \mathrm{~m}$ long obstacles, a steel truss bridge is the most economical type. The purpose of this study is to redesign the upper structure of the Mesim River Bridge and to obtain effective upper structure dimensions. This plan refers to SNI 1725:2016 about bridge loading, RSNI T-03-2005 about steel structure planning for bridges, and SNI T-12-2004 about concrete structure planning. This bridge is planned with a length of $52 \mathrm{~m}$ in 1 span, width $7 \mathrm{~m}$, and height $6,45 \mathrm{~m}$. Based on planning results uses warren type truss, the bridge slab thickness is $200 \mathrm{~mm}$, stringer uses IWF 350.175.7.11, cross girder uses IWF 700.300.13.24, the main truss uses IWF 400.400.13.21
\end{abstract}

Keywords: Upper structure, steel truss, bridge

(C) 2021 Universitas Abdurrab ISSN 2527-7073

Alamat : indriyani_p@polbeng.ac.id

E-mail: rizki.laylakumala99@gmail.com 


\section{PENDAHULUAN}

Layla Kumala Rizki, Indriyani Puluhulawa / Jurnal Rab Contruction Research 6 (2) (2021)

Salah satu faktor untuk mendukung peningkatan taraf hidup masyarakat adalah pergerakan transportasi. Agar keberlangsungan transportasi berjalan lancar maka harus tersedia sarana dan prasarana yang memadai. Jalan dan jembatan merupakan prasarana yang harus dipersiapkan. Ditinjau dari kondisi geografisnya, terdapat beberapa sungai yang mengaliri Pulau Rupat. Salah satunya adalah Sungai Mesim yang terletak di Desa Sukarjo Mesim dengan lebar sungai 50,9 m. Sebagai penghubung akses lalu lintas maka diperlukan adanya jembatan.

Dinas Pekerjaan Umum dan Penataan Ruang (PUPR) melaksanakan pembangunan Jembatan Sungai Mesim dengan tipe beton bertulang. Jembatan Sungai Mesim ini dibangun dengan 2 bentang. Kedua bentang jembatan memiliki ukuran yang hampir sama. Betang pertama pada Jembatan Sungai Mesim melintasi sungai. Sedangkan pada bentang kedua melintasi rawa. Antara bentang pertama dan bentang kedua dipisahkan oleh tanah timbunan dan plat lantai kendaraan.

Berdasarkan peraturan Bina Marga tahun 2015 untuk rintangan sepanjang 40 hingga 200 meter maka jenis jembatan yang paling ekonomis adalah rangka baja. Hal ini dikarenakan baja lebih efektif dengan memiliki nilai kuat tarik dan kuat tekan yang lebih besar daripada beton.

Dengan mengikuti panduan bentang ekonomis yang telah ditetapkan Bina Marga, maka dilakukan perancangan ulang struktur atas Jembatan Sungai Mesim menggunakan rangka baja. Diharapkan hasil perancangan ini dapat menjadi alternatif desain dan memberikan desain struktur atas Jembatan Sungai Mesim yang efektif.

Penelitian ini bertujuan untuk memperoleh rancangan struktur atas Jembatan Sungai Mesim dengan dimensi yang efektif, mengacu pada aturan terbaru SNI 1725:2016 tentang pembebanan jembatan.

\section{TINJAUAN PUSTAKA}

Pedoman bentang ekonomis berdasarkan Surat Edaran Ditjen Bina Marga nomor 07/SE/M/2015 pemilihan jenis jembatan berdasarkan panjang bentang dapat dilihat pada Tabel 1 sebagai berikut.

Tabel 1 Pedoman Umum Bentang Ekonomis (Bina Marga, 2015)

\begin{tabular}{c|c}
\hline Jenis Jembatan & Bentang Max. (m) \\
\hline Flat Slab Beton & $0-15$ \\
\hline Gelagar Beton T & $10-18$ \\
\hline Modi Gelagar Beton T & $18-25$ \\
\hline Box Beton Bertulang & $25-40$ \\
\hline Box Free Cantilever & $40-300$ \\
\hline Rangka Baja & $40-200$ \\
\hline Pelengkung Baja & $150-400$ \\
\hline Cable Stayed & $200-500$ \\
\hline Gantung & $300-2000$ \\
\hline Composite bridge & $15,00-35,00$ \\
\hline
\end{tabular}

Perhitungan pembebanan dalam perancangan struktur atas jembatan yang dilakukan mengacu kepada SNI 1725:2016.

A. Beban Mati

Beban mati terdiri dari berat sendiri (MS) dan beban mati tambahan (MA). Berat sendiri (MS) adalah berat setiap elemen struktur ditambah elemen non structural yang dianggap tetap. Sedangkan beban mati tambahan (MA) adalah seluruh beban non structural pada jembatan yang besarnya dapat berubah selama umur jembatan.

B. Beban Hidup (Beban Lalu Lintas)

1. Beban Lajur (TD)

Beban lajur "D" merupakan gabungan dari terbagi rata (BTR) dan beban garis terpusat (BGT) seperti terlihat dalam Gambar 1 berikut 


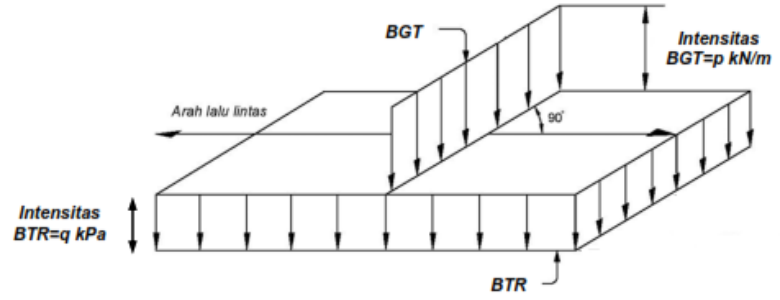

Gambar 1. Beban Lajur (SNI 1725:2016)

Besarnya intensitas $q \mathrm{kPa}$ dalam beban terbagi rata (BTR) sesuai dengan panjang total jembatan yang dibebani $\mathrm{L}$

$L \leq 30 \mathrm{~m}: q=9,0 \mathrm{kPa}$

$L>30 \mathrm{~m}: q=9,0\left(0,5+\frac{15}{\mathrm{~L}}\right) \mathrm{kPa}$

Intensitas beban garis terpusat (BGT)

2. Beban Truk (TT)

Susunan pembebanan truk dapat dilihat pada Gambar 2 berikut
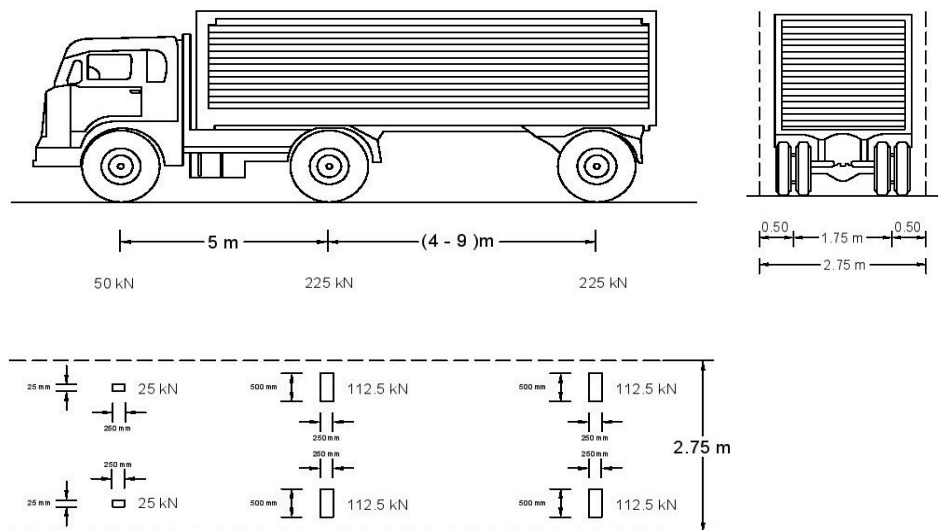

3. Gaya Rem (TB)

Gambar 2. Beban Lajur (SNI 1725:2016)

Pengaruh percepatan dan pengereman dari lalu-lintas harus diperhitungkan sebagai gaya dalam arah memanjang dan dianggap bekerja pada permukaan lantai jembatan Berdasarkan SNI 1725:2016 gaya rem harus diambil yang terbesar dari:

1. $25 \%$ dari berat gandar truk desain atau,

2. $5 \%$ dari berat truk rencana ditambah beban lajur terbagi rata BTR

C. Pembebanan Untuk Pejalan Kaki (TP)

Trotoar yang memiliki lebar lebih dari $600 \mathrm{~mm}$ harus dihitung dengan memikul beban pejalan kaki sebesar $5 \mathrm{kPa}$ yang dianggap bekerja secara bersamaan dengan beban kendaraan pada masing-masing lajur kendaraan.

D. Beban Akibat Aksi Lingkungan

1. Beban Angin (Ew)

2. Pengaruh Temperatur (ET)

Pembebanan temperatur jembatan rata-rata nominal dapat dilihat pada Tabel 2 berikut

Tabel 2 Temperatur Jembatan Rata-Rata Nominal (SNI 1725:2016)

\begin{tabular}{l|c|c}
\hline \multicolumn{1}{c|}{ Tipe Bangunan Atas } & $\begin{array}{c}\text { Temperatur Jembatan } \\
\text { Rata-rata Minimum (1) }\end{array}$ & $\begin{array}{c}\text { Temperatur Jembatan } \\
\text { Rata-rata Maksimum (2) }\end{array}$ \\
\hline $\begin{array}{l}\text { Lantai beton di atas gelagar atau } \\
\text { boks beton. }\end{array}$ & $15^{\circ} \mathrm{C}$ & $40^{\circ} \mathrm{C}$ \\
\hline $\begin{array}{l}\text { Lantai beton di atas gelagar, boks } \\
\text { atau rangka baja. }\end{array}$ & $15^{\circ} \mathrm{C}$ & $40^{\circ} \mathrm{C}$ \\
\hline
\end{tabular}


Hasil perhitungan beban yang terjadi kemudian dihitung sesuai kombinasi pembebanan yang terdapat dalam SNI 1725:2016. Kombinasi pembebanan terdiri dari Kuat I, Kuat II, Kuat III, Kuat IV, Kuat V, Ekstrem I, Ekstrem II, Layan I, Layan II, Layan III, dan Layan IV.

\section{METODE}

A. Tempat dan Waktu Penelitian

Lokasi penelitian bertempat di Jalan Soebrantas, Desa Sukarjo Mesim, Kecamatan Rupat. Waktu pelaksanaan penelitian ini dilakukian pada Bulan Maret sampai dengan Bulan Agustus 2021. Lokasi penelitian dapat dilihat pada Gambar 3 berikut:

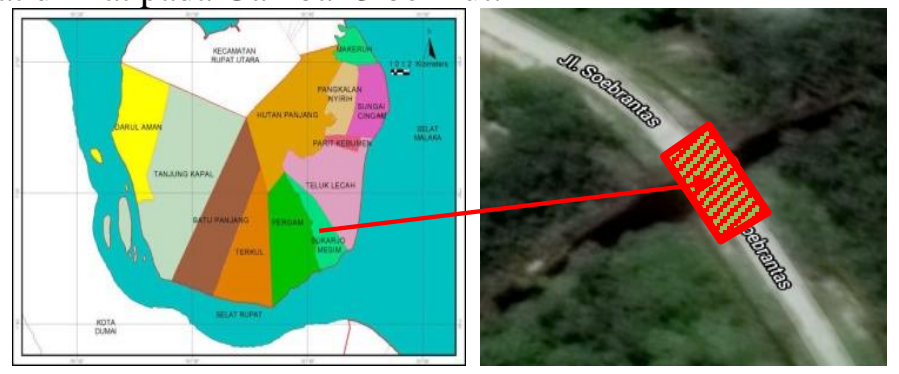

Gambar 3 Lokasi Penelitian

B. Tahap Penelitian

Berikut tahapan-tahapan yang dilakukan dalam melakukan penelitian ini yaitu:

1. Studi Literatur

Adapun literatur yang digunakan dalam penelitian ini adalah SNI 1725-2016 tentang Perencanaan Pembebanan Jembatan, RSNI T-03-2005 tentang Perencanaan Struktur Baja Untuk Jembatan, SNI T-12-2004 tentang Perencanaan Struktur Beton, dan literatur lain seperti buku, jurnal serta ianternet.

2. Pengumpulan Data

Data yang diperlukan dalam penelitian ini adalah data primer dan data sekunder. Data Primer yang dibutuhkan antara lain adalah profil melintang sungai dan tinggi Muka Air Banjir. Sedangkan data sekunder yang dibutuhkan yaitu data kelas jalan pada lokasi penelitian.

3. Pemilihan Tipe Jembatan

Tipe jembatan dipilih berdasarkan Pedoman Umum Bentang Ekonomis 07/SE/M/2015.

Maka dipilih jembatan rangka baja yang ekonomis untuk bentang jembatan 40-200 m.

4. Pemilihan Tipe Rangka Jembatan

Tipe rangka jembatan dipilih adalah tipe warren. Kemudian dilakukan permodelan rangka secara 3 dimensi dalam SAP 2000.

5. Pembebanan

Pembebanan jembatan merujuk pada aturan pembebanan terbaru yaitu SNI 1725:2016 tentang Pembeban Jembatan.

6. Analisis Perhitungan Struktur Atas

Pada tahap ini dilakukan perencanaan struktur atas sehingga diperloeh dimensi-dimensi yang aman untuk menahan beban yang diterima oleh jembatan tersebut. Adapun struktur atas yang direncanakan dalam penelitian ini yaitu slab, trotoar, gelagar melintang, gelagar memanjang, rangka utama, ikatan angin dan sambungan.

7. Kontrol Aman

Tahapan ini merupakan tahapan untuk memeriksa keamanan struktur atas. Dimensi struktur atas yang direncanakan harus aman terhadap momen, geser dan lendutan yang terjadi. 
8. Penggambaran Hasil Perencanaan

Hasil perencanaan menggunakan bantuan perangkat lunak (software) Auto Cad. Penggambaran dilakukan dengan memperhatikan etika-etika penggambaran.

\section{HASIL DAN PEMBAHASAN}

A. Data Teknis Jembatan

Data primer berupa profil melintang sungai digunakan untuk merencanakan panjang jembatan. Sedangkan data sekunder berupa kelas jalan digunakan untuk perhitungan beban truk pada jembatan tersebut. Adapun data teknis jembatan dapat dilihat pada Tabel 3 berikut.

Tabel 3 Data Teknis Jembatan

\begin{tabular}{l|c}
\hline \multicolumn{1}{c|}{ Data Teknis Jembatan } & Keterangan \\
\hline Panjang jembatan & $52 \mathrm{~m}$ \\
\hline Lebar jembatan & $7 \mathrm{~m}$ \\
\hline Tinggi rangka jembatan & $6,45 \mathrm{~m}$ \\
\hline Jumlah lajur & 1 lajur 2 arah \\
\hline Lebar jalur lalu lintas & $6 \mathrm{~m}$ \\
\hline Lebar trotoar & $2 \times 0,5 \mathrm{~m}$ \\
\hline Jumlah gelagar memanjang & $5 \mathrm{buah}$ \\
\hline Jarak antar gelagar memanjang & $1,5 \mathrm{~m}$ \\
\hline Jumlah gelagar melintang & 11 buah \\
\hline Jarak anatar gelagar melintang & $5,2 \mathrm{~m}$ \\
\hline Jumalah segmen & 10 segmen \\
\hline
\end{tabular}

B. Pembebanan

Tipe rangka yang direncanakan adalah warren truss. Kemudian dilakukan permodelan rangka jembatan dalam SAP 2000 dan dilakukan input pembebanan seperti pada Gambar 4 sampai Gambar 13. Hasil analisa SAP 2000 berupa gaya aksial tekan dan gaya aksial tarik yang diterima stiap batang digunakan dalan perencanaan batang tarik dan batang tekan.

1. Berat Sendiri (Ms)

Berat sendiri trotoar $=$ Tebal trotoar $\times \gamma_{\text {beton bertulang }}=6 \mathrm{kN} / \mathrm{m}^{2}$

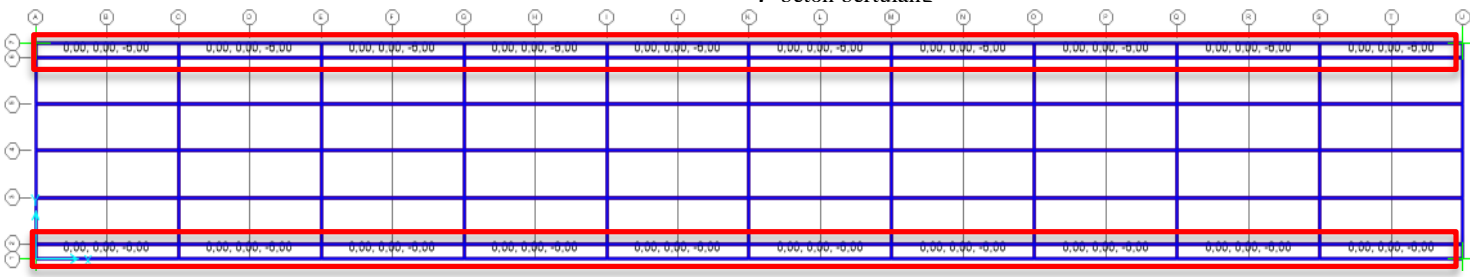

Gambar 4 Input beban Pembebanan Trotoar di SAP 2000

2. Beban Mati Tambahan (MA)

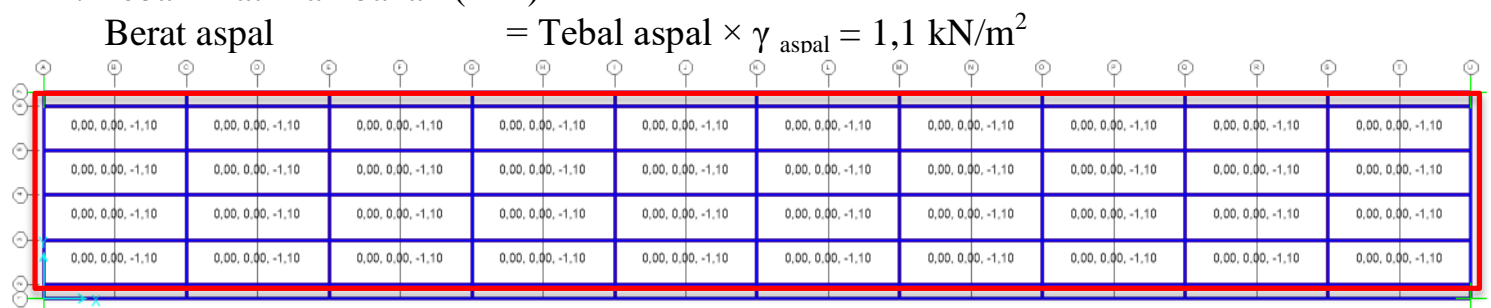

Gambar 5 Pembebanan Aspal di SAP 2000

Berat air hujan

$=$ Tebal air hujan $\times \gamma_{\text {air hujan }}=0,49 \mathrm{kN} / \mathrm{m}^{2}$ 


\begin{tabular}{|c|c|c|c|c|c|c|c|c|c|}
\hline $0,00,0.00, \cdot 0.49$ & $0,00,0.00 \cdot 0.49$ & $0.00,0.00,-0.49$ & $0,00,0.00,-0.49$ & $0.00,0.00,-0.49$ & $0.00,0.00,0.49$ & $0.00,0.00,-0.49$ & $0,00,0.90,0.49$ & $0.00,0.00,-0.49$ & $0.00,0.00,-0.49$ \\
\hline $0.00,0.000 \cdot 0.49$ & $0.00,0.000 \cdot 0.49$ & $0.00 \cdot 0.000 \cdot 0.49$ & $0.00,0.000,-0.49$ & $0.00,0.00 \cdot 0.49$ & $0.00,0.00 \cdot \cdot 0.49$ & $0.00,0.90 \cdot .0 .48$ & $0.00 \cdot 0.000 \cdot 0.49$ & $0.00,0.00, \cdot 0.49$ & $0.00,0.00, \cdot 0.49$ \\
\hline $0.00,0.000,0.49$ & $0.00,0.00 \cdot 0.49$ & $0.00,0.000 \cdot 0.49$ & $0,00,0.00,-0.49$ & $0.00,0.00 \cdot-0.49$ & $0.00,0.00 \cdot \cdot 0.49$ & $0.00,0.00, \cdot 0.49$ & $0.00,0.00,-0.49$ & $0.00,0.00, \cdot 0.49$ & $0.00,0.00,-0.49$ \\
\hline $0,00,0.00,-0.49$ & $0.00,0.00, \cdot 0.49$ & $0,00,0.00,-0,40$ & $0,00,0.00,-0,49$ & $0,00,0.00,-0.49$ & $0.00,0.00, \cdot 0.49$ & $0.00,0.00 \cdot 0.49$ & $0,00,0.90,-0,49$ & $0,00,0.00 \cdot 0.49$ & $0.00,0.00,-0.49$ \\
\hline
\end{tabular}

Gambar 6 Pembebanan Air Hujan di SAP 2000

Berat steel deck $=0,0735 \mathrm{kN} / \mathrm{m}^{2}$

\begin{tabular}{|c|c|c|c|c|c|c|c|c|c|}
\hline (i) & (우 & (1) & (1) & (ㄹ) & (ㄷ) & (i) & (e) & (8) & (1) \\
\hline 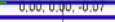 & 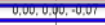 & 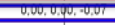 & $0,0,0,0,0,0,0,0,0$ & 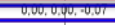 & 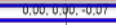 & 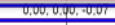 & (1) & 0,00 & . \\
\hline $0,00,0.00 \cdot-0.07$ & $0.00,0.00, \cdot 0.07$ & $0,00,0.00,-0.07$ & $0,00,0.00,-0.07$ & $0,00,0.00 \cdot \cdot 0.07$ & $0,00,0.00,-0.07$ & $0.00,0.00,0.07$ & $0.00,0.00, \cdot 0.07$ & $0.00,0.000,-0.07$ & $0,00,0.00, \cdot 0.07$ \\
\hline $0.00,0.00 \cdot 0.07$ & $0.00,0.00,-0.07$ & $0.00,0.00,-0.07$ & $0.00,0.00 \cdot \cdot 0.07$ & $0,00,0.90 \cdot 0.07$ & $0,00,0.00 \cdot \cdot 0.07$ & $0.00,0.00, \cdot 0.07$ & $0,000,0.00 \cdot 0.07$ & $0.00,0.00 \cdot 0.07$ & $0.00,0.00,-0.07$ \\
\hline $0.00,0.00 \cdot \cdot 0.07$ & $0.00,0.00,-0.07$ & $0.00,0.90 \cdot-0.07$ & $0,00,0.90 \cdot-0.07$ & $0,00,0.00 \cdot \cdot 0.07$ & $0.00,0.00,-0.07$ & $0,00,0.00,-0.07$ & $0,00,0.00 \cdot \cdot 0.07$ & $0,00,0.00,-0.07$ & $0.00,0.00,-0.07$ \\
\hline $0,00,0.00, \cdot 0.07$ & $0,00,0.00,=0.07$ & $0.00,0.00,-0.07$ & $0.00,0.00 \cdot 0.07$ & $0.00,0.00,-0.07$ & $0,00,0.00,-0.07$ & $0.00,0.00,=0.07$ & $0,00,0.00, \cdot 0.07$ & $0.00,0.00, \cdot 0.07$ & $0.00,0.00, \cdot 0.07$ \\
\hline
\end{tabular}

Gambar 7 Pembebanan Steel Deck di SAP 2000

3. Beban Lajur (TD)

Beban lajur terdiri atas beban terbagi rata (BTR) yang digabungkan dengan beban garis (BGT). Beban terbagi rata (BTR)

$\mathrm{L}>30 \mathrm{~m}: \quad \mathrm{q}=9,0(0,5+15 / \mathrm{L}) \mathrm{kPa}=7,096 \mathrm{kPa}=7,096 \mathrm{kN} / \mathrm{m}^{2}$

\begin{tabular}{|c|c|c|c|c|c|c|c|c|c|}
\hline (i) & Q & (i) & i & i & (i) & (i) & 甲 & (9) & i \\
\hline $0.00,0.090,-7,10$ & $0.000 .0 .090 \cdot 7,7.10$ & $0.00,0.000 .7 .7 .10$ & $0.000 .0 .90 \cdot 7.7 .10$ & $0.000 .0 .00 \cdot-7,7,10$ & $0.000 .0 .000 \cdot 7.7 .10$ & $0,000,0.090,-7,710$ & 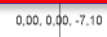 & $0,00,0.000 .7,7,10$ & $0.000 .0 .00 \cdot \cdot 7.710$ \\
\hline $0,00,0.000 \cdot 7,7.10$ & $0.000 .0 .00 \cdot .7,10$ & $0.000,0.00 \cdot, 7,1,10$ & $0,000,0,000,7,7,10$ & $0.000,0.000,-7,10$ & 0.00 .0 .000 .7 .10 & $0,00,0.090,-7.10$ & 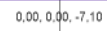 & $0.000,0.00,-7,10$ & 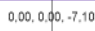 \\
\hline $0.00,0.090 \cdot 7.7 .10$ & $0.000 .0 .00 \cdot .7 .10$ & $0.000 .0 .90, \cdot 7.1,10$ & $0.000 .0 .00 \cdot \cdot 7,1.10$ & $0.000 .0 .00 \cdot .7,710$ & $0.000 .0 .90 \cdot \cdot 7.110$ & $0.000,0.00 \cdot-7.710$ & 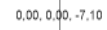 & $0.000 .0 .00,7.7,10$ & $0.00,0.00, \cdot 7.10$ \\
\hline $0,00,0.090 \cdot 7.7 .10$ & $0.000,0.090,7,7,10$ & $0,000,0.00, \cdot 7,1.10$ & $0.000 .000 \cdot \cdot 7,1,10$ & $0.000,0.00, \cdot 7,10$ & $0,000,0.090 \cdot 7.110$ & $0,000,0.09 \cdot, 7,710$ & $0,00,0.090,7.710$ & $0.000,0.00,-7,10$ & $\begin{array}{l}0.00,0.00,-7.10 \\
\end{array}$ \\
\hline
\end{tabular}

Gambar 8 Beban Terbagi Rata di SAP 2000

Penempatan beban $\mathrm{P}$ di tengah bentang jembatan. Besarnya intesitas $\mathrm{p}$ adalah sebesar 49 $\mathrm{kN} / \mathrm{m}$. Nilai FBD yaitu $39,5 \%$

$$
\mathrm{P}=(1+\mathrm{FBD}) \times \mathrm{p}=68,355 \mathrm{kN} / \mathrm{m}
$$

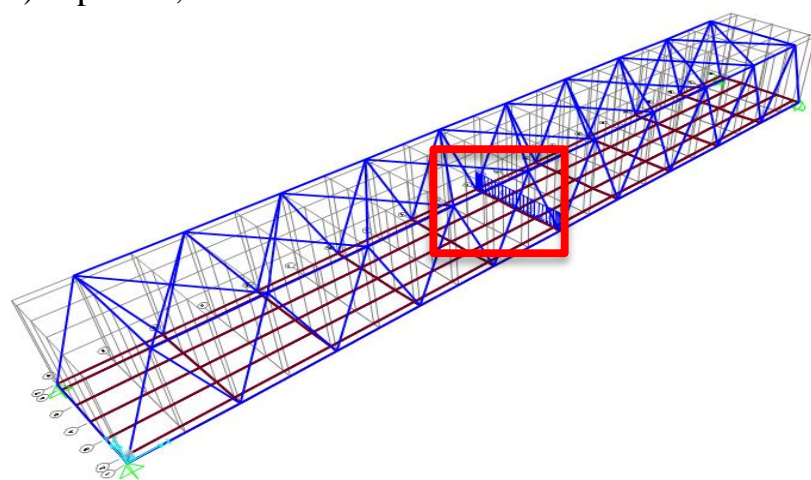

Gambar 9 Beban Garis Terpusat di SAP 2000

4. Gaya Rem (TB)

$25 \%$ PTT

$5 \%$ Berat Truk Rencana + BTR

$$
\begin{aligned}
& =41,85 \mathrm{kN} \\
& =126,2 \mathrm{kN} \\
& =126,2 \mathrm{kN} \\
& =55 \text { join } \\
& =2,295 \mathrm{kN}
\end{aligned}
$$

Gaya rem/join

Beban akibat gaya rem di input dalam SAP 2000 pada setiap join yang terdapat pada lajur. 


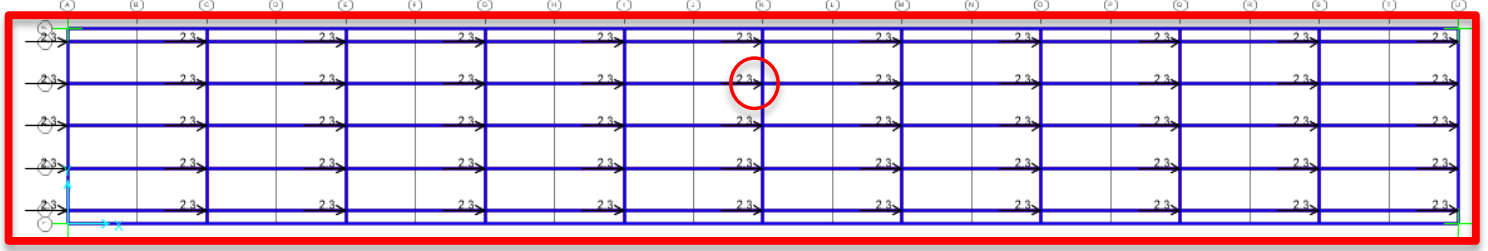

Gambar 10 Beban Rem

5.Beban Angin (Ew)

Beban angin pada struktur

$\mathrm{V}_{\mathrm{DZ}}=163,741 \mathrm{~km} / \mathrm{jam}$

Angin tekan $\quad=0,004 \mathrm{~N} / \mathrm{mm}<4,4 \mathrm{~N} / \mathrm{mm}$ maka diambil 4,4 N/mm 2

Angin hisap $\quad=0,002 \mathrm{~N} / \mathrm{mm}<2,2 \mathrm{~N} / \mathrm{mm}$ maka diambil $2,2 \mathrm{~N} / \mathrm{mm}^{2}$ Jumlah join $=21$ join

$30 \%$ luas rangka $=30 \% \times((46,8+52) \times 6,45) / 2=95,589 \mathrm{~m}^{2}$

Beban angin tekan/join $=(4,4 \times 95,589) / 21=20,03 \mathrm{kN}$

Beban angin hisap/join $=(2,2 \times 95,589) / 21=10,01 \mathrm{kN}$

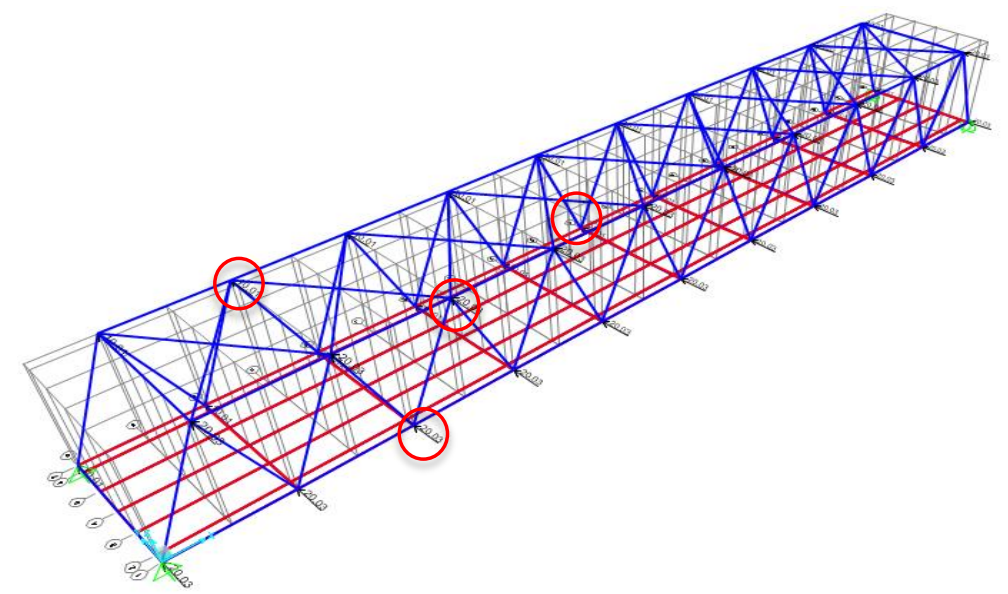

Gambar 10 Beban Angin yang Meniup Struktur

Angin yang meniup kendaraan

$\mathrm{Q}_{\text {angin }} \quad=1,460 \mathrm{~N} / \mathrm{mm}$

Jarak beban diatas jalan sebesar $1800 \mathrm{~mm}$

Tebal aspal $=50 \mathrm{~mm}$, tebal overlay $=50 \mathrm{~mm}$, tebal slab $=200 \mathrm{~mm}, 1 / 2 \mathrm{H}$ gelagar melintang= $400 \mathrm{~mm}$

Total jarak beban

$=2500 \mathrm{~mm}$

Beban pada gelagar

$=\mathrm{Q}$ angin $\times$ Total jarak

$=11$ join

$=3,650 / 11$

$$
=3,650 \mathrm{kN}
$$

Jumlah join bawah

Beban angin/join

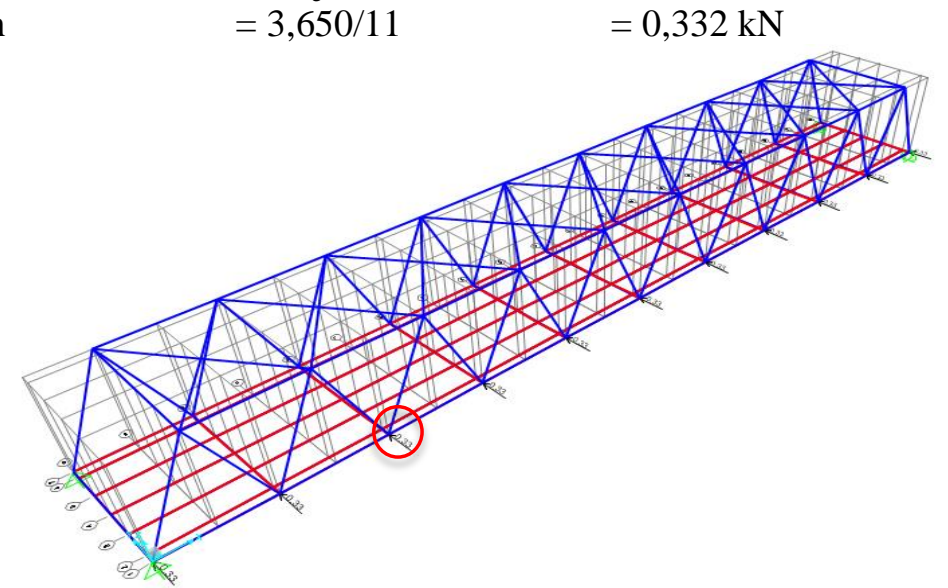


6. Beban Pejalan Kaki (TP)

Trotoar direncanakan memikul beban $5 \mathrm{kPa}=5 \mathrm{kN} / \mathrm{m}^{2}$

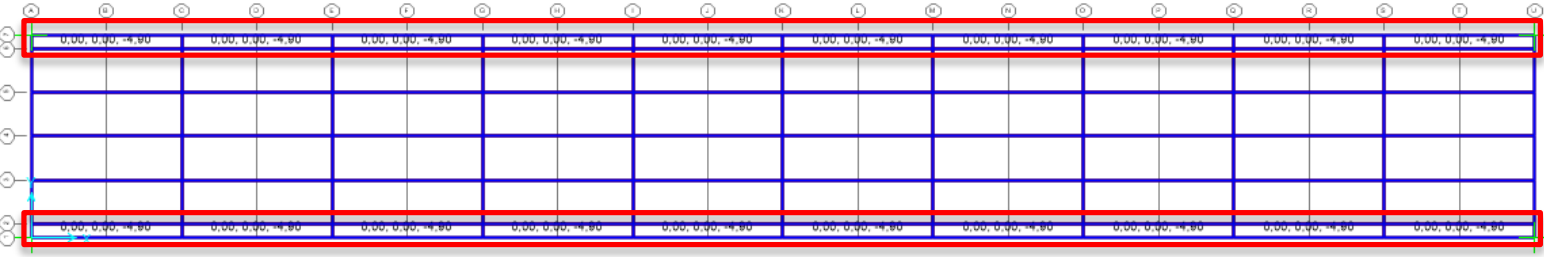

Gambar 12 Beban Pejalan Kaki

7. Beban Temperatur (ET)

$$
\Delta T=\frac{T_{\max }-T_{\min }}{2}=\frac{40^{\circ} \mathrm{C}-15 \mathrm{C}}{2}=12,5^{\circ} \mathrm{C}
$$

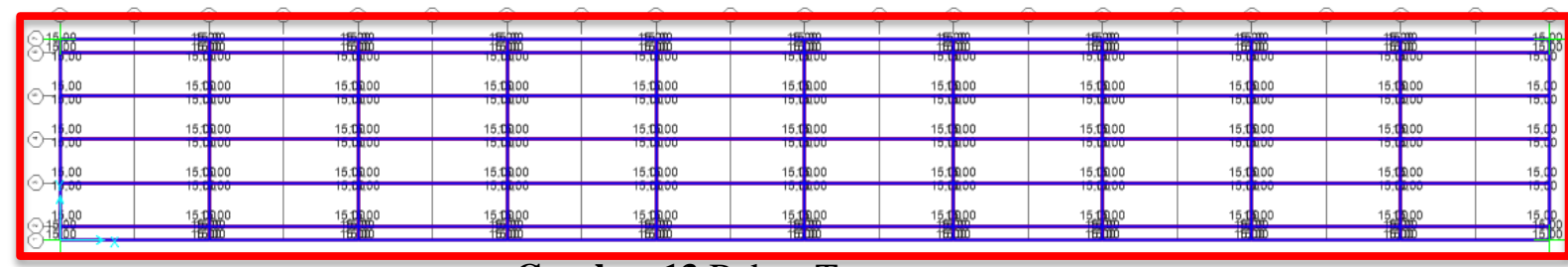

Gambar 13 Beban Temperatur

Berdasarkan hasil analisis SAP 2000 diperoleh gaya aksial seperti Tabel 4 berikut.

Tabel 4 Gaya Aksial Hasil Analisis SAP 2000

\begin{tabular}{|c|l|c|}
\hline \multicolumn{2}{|c|}{ Batang } & Hasil Maksimum $(\mathrm{kN})$ \\
\hline \multirow{3}{*}{ Tekan } & Batang atas & 5376,103 \\
\cline { 2 - 3 } & Batang diagonal & 2426,308 \\
\cline { 2 - 3 } & Ikatan angin & 27,577 \\
\hline \multirow{3}{*}{ Tarik } & Batang bawah & 1848,575 \\
\cline { 2 - 3 } & Batang diagonal & 2304,832 \\
\cline { 2 - 3 } & Katan angin & 10,491 \\
\hline
\end{tabular}

C. Perencanaan Slab Jembatan

1. Analisa Pembebanan Slab Jembatan

Hasil perhitungan dari beban-beban pada slab jembatan yaitu $\mathrm{Q}_{\mathrm{MS}}=5 \mathrm{kN} / \mathrm{m}, \mathrm{Q}_{\mathrm{MA}}=3,19$

$\mathrm{kN} / \mathrm{m}, \mathrm{P}_{\mathrm{TT}}=60,543 \mathrm{kN}, \mathrm{P}_{\mathrm{EW}}=1,008 \mathrm{kN} / \mathrm{m}, \Delta \mathrm{T}=12,5^{\circ} \mathrm{C}$

2. Perhitungan Momen Slab Jembatan

Terdapat dua jenis momen pada slab jembatan yaitu momen tumpuan dan momen lapangan. Adapun hasil perhitungan momen tumpuan dan momen lapangan dapat dilihat pada Tabel 5 berikut

Tabel 5 Momen pada Slab Jembatan

\begin{tabular}{c|l|c|c}
\hline No & \multicolumn{1}{|c|}{ Jenis Beban } & $\begin{array}{c}\text { M } \\
\text { Tumpuan }\end{array}$ & M Lapangan \\
\hline 1 & Berat sendiri & 0,9 & 0,469 \\
\hline 2 & Beban mati tambahan & 0,748 & 0,374 \\
\hline 3 & Beban Truk & 14,190 & 12,771 \\
\hline 4 & Beban angin & 0,236 & 0,213 \\
\hline 5 & Pengaruh temperatur & 0,006 & 0,031 \\
\hline
\end{tabular}

Kemudian momen yang diperoleh dihitung dengan faktor kombinasi beban yang merujuk SNI 1725:2016. Hasil kombinasi beban pada momen tumpuan dan momen lapangan maksimum sama-sama diperoleh dari kombinasi kuat I yaitu $28,2 \mathrm{kNm}$ dan $24,3 \mathrm{kNm}$. 
3. Perhitungan Tulangan Slab Jembatan

a) Perencanaan Tulangan Tumpuan (Tulangan Lentur Negatif)

Perencanaan tulangan tumpuan (tulangan lentur negatif) pada slab jembatan dihitung berdasarkan nilai kombinasi komen tumpuan maksimum yaitu sebesar $28,3 \mathrm{kNm}$. Tebal slab jembatan yang direncanakan adalah $200 \mathrm{~mm}$, mutu beton K-350, tebal selimut beton $35 \mathrm{~mm}$ dan baja tulangan U-32. Luas tulangan yang diperlukan $\mathrm{A}_{\mathrm{s} \text { Perlu }}=592,308$ $\mathrm{mm}^{2}$. Tulangan utama direncanakan menggunakan diameter $16 \mathrm{~mm}$ dan jarak pemasangan $300 \mathrm{~mm}$. Luas tulangan yang terpasang diperoleh sebesar $\mathrm{A}_{\mathrm{s}}$ Pasang = $670,206 \mathrm{~mm}^{2}$.

Dalam perencanaan tulangan bagi/susut diambil luas tulangan yang diperlukan $50 \%$ dari luas tulangan pokok yang diperlukan $A_{\mathrm{s}}$ perlu $=296,154 \mathrm{~mm}^{2}$. Direncanakan menggunakan tulangan dengan diameter $10 \mathrm{~mm}$ dan jarak pemasangan $250 \mathrm{~mm}$. Luas tulangan yang terpasang diperoleh sebesar $A_{\mathrm{s}}$ Pasang $=314,159 \mathrm{~mm}^{2}$.

Berdasarkan hasil perhitungan tulangan utama dan tulangan bagi diperoleh luas tulangan yang terpasang lebih besar dari luas tulangan yang diperlukan sehingga tulangan tersebut aman digunakan.

b) Perencanaan Tulangan Lapangan (Tulangan Lentur Positif)

Perencanaan tulangan lapangan (tulangan lentur positif) pada slab jembatan dihitung berdasarkan nilai kombinasi komen lapangan maksimum yaitu sebesar $24,3 \mathrm{kNm}$. Tebal slab jembatan yang direncanakan adalah $200 \mathrm{~mm}$, mutu beton K-350, tebal selimut beton $35 \mathrm{~mm}$. Untuk menahan momen lapangan (momen positif) digunakan steel deck dengan tegangan leleh $550 \mathrm{MPa}$ dan tebal 0,7 $\mathrm{mm}$. Berdasarkan perhitungan diperoleh tahanan momen positif yang diizinkan sebesar $54 \mathrm{kNm}$. Nilai tersebut lebih besar dari momen positif yang terjadi sehingga steel deck aman digunakan sebagai tulangan lapangan (tulangan lentur positif).

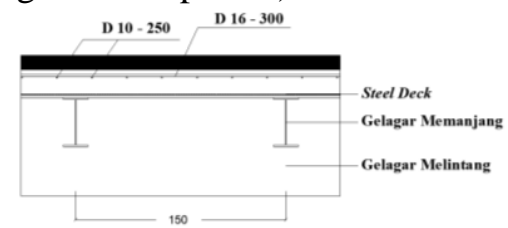

Gambar 14 Pembesian Slab Jembatan

Jadi dapat disimpulkan bahwa untuk perencanaan slab jembatan dengan nilai momen negatif sebesar $28,3 \mathrm{kNm}$, momen poditif sebesar $24,3 \mathrm{kNm}$, tebal slab $200 \mathrm{~mm}$, baja tulangan U-39, dan mutu beton K-350, digunakan tulangan lentur negatif D 16 dengan jarak $300 \mathrm{~mm}$ dan tulangan bagi D 10 dengan jarak $250 \mathrm{~mm}$. Sedangkan untuk menahan momen positif digunakan steel deck dengan tegangan leleh $550 \mathrm{MPa}$ dan tebal $0,7 \mathrm{~mm}$.

Dalam (Amadi, Fahrul 2020) diperoleh hasil perhitungan momen positif dan negatif hampir sama yaitu $26,273 \mathrm{kNm}$ dan $22,697 \mathrm{kNm}$. Untuk menahan momen negatif tulangan yang digunakan D $16 \mathrm{~mm}$ dengan jarak pemasangan ini lebih rapat yaitu $200 \mathrm{~mm}$ dan untuk tulang susut, tulangan dan jarak pemasangan berbeda yaitu D $13 \mathrm{~mm}$ dengan jarak $300 \mathrm{~mm}$. Sedangkan dalam menahan momen positif tidak menggunakan steel deck tetapi menggunakan tulangan utama D 16 dengan jarak pemasangan $200 \mathrm{~mm}$ dan tulangan bagi D13 dengan jarak pemasangan $300 \mathrm{~mm}$.

D. Perencanaan Trotoar

1. Analisa Pembebanan Trotoar

Hasil perhitungan dari pembebanan pada trotoar yaitu $\mathrm{P}_{\mathrm{MS}}=5,625 \mathrm{kN}, \mathrm{P}_{\mathrm{MA}}=0,245 \mathrm{kN} / \mathrm{m}$, $\mathrm{P}_{\mathrm{TP} 1}=2,5 \mathrm{kN}, \mathrm{mP}_{\mathrm{TP} 2}=2,5 \quad \mathrm{kN}$

2. Perhitungan Momen Trotoar

Adapun pehitungan momen pada trotoar dapat dilihat dari Tabel 6 berikut

Tabel 6 Momen pada Trotoar

Jenis Beban

Beban $(\mathrm{kN})$

Lengan

Momen (kNm) 
Layla Kumala Rizki, Indriyani Puluhulawa / Jurnal Rab Contruction Research 6 (2) (2021)

\begin{tabular}{l|c|c|c|c|c}
\hline Berat sendiri & $\mathrm{P}_{\mathrm{MS}}$ & 5,625 & 0,25 & $\mathrm{M}_{\mathrm{MS}}$ & 1,406 \\
\hline Beban mati tambahan & $\mathrm{P}_{\mathrm{MA}}$ & 0,245 & 0,25 & $\mathrm{M}_{\mathrm{MA}}$ & 0,061 \\
\hline Beban hidup merata & $\mathrm{P}_{\mathrm{TP} 1}$ & 2,5 & 0,25 & $\mathrm{M}_{\mathrm{TP} 1}$ & 0,625 \\
\hline Beban horizontal pada kerb & $\mathrm{P}_{\mathrm{TP2}}$ & 2,5 & 0,45 & $\mathrm{M}_{\mathrm{TP2}}$ & 1,125 \\
\hline \multicolumn{4}{l|}{ Total }
\end{tabular}

Hasil momen yang diperoleh dihitung dengan faktor kombinasi beban sesuai dengan SNI 1725:2016 sehingga diperoleh hasil momen ultimit seperti pada Tabel 7.

Tabel 7 Momen Terfaktor pada Trotoar

\begin{tabular}{l|c|c|c|c}
\hline \multicolumn{1}{c|}{ Jenis Beban } & \multicolumn{2}{|c|}{ Faktor Beban Ultimit } & $\begin{array}{c}\text { Momen } \\
(\mathrm{kNm})\end{array}$ & $\begin{array}{c}\text { Momen Terfaktor } \\
(\mathrm{kNm})\end{array}$ \\
\hline Berat sendiri & $\mathrm{M}_{\mathrm{MS}}$ & 1,3 & 1,406 & 1,828 \\
\hline Beban mati tambahan & $\mathrm{M}_{\mathrm{MA}}$ & 2 & 0,061 & 0,123 \\
\hline Beban hidup merata & $\mathrm{M}_{\mathrm{TP} 1}$ & 1,8 & 0,625 & 1,125 \\
\hline Beban horizontal pada kerb & $\mathrm{M}_{\mathrm{TP} 2}$ & 1,8 & 1,125 & 2,025 \\
\hline \multicolumn{4}{l|}{ MU }
\end{tabular}

3. Perhitungan Tulangan Trotoar

Trotoar direncanakan dengan tebal $250 \mathrm{~mm}$, mutu beton K-300, tebal selimut beton 35 $\mathrm{mm}$ dan baja tulangan U-32. Luas tulangan yang diperlukan $\mathrm{A}_{\mathrm{s}}$ Perlu $=721,875 \mathrm{~mm}^{2}$. Direncanakan menggunakan tulangan dengan diameter $16 \mathrm{~mm}$ dan jarak pemasangan $250 \mathrm{~mm}$. Luas tulangan yang terpasang diperoleh sebesar $A_{\mathrm{s}}$ Pasang $=804,248 \mathrm{~mm}^{2}$. Dalam perencanaan tulangan bagi/susut diambil luas tulangan yang diperlukan $50 \%$ dari luas tulangan pokok yang diperlukan $A_{s}$ perlu $=360,938 \mathrm{~mm}^{2}$. Direncanakan menggunakan tulangan dengan diameter $10 \mathrm{~mm}$ dan jarak pemasangan $200 \mathrm{~mm}$. Luas tulangan yang terpasang diperoleh sebesar $A_{\mathrm{s}}$ Pasang $=392,699 \mathrm{~mm}^{2}$.

Berdasarkan hasil perhitungan tulangan utama dan tulangan bagi diperoleh luas tulangan yang terpasang lebih besar dari luas tulangan yang diperlukan sehingga tulangan tersebut aman digunakan, seperti terlihat pada Gambar 5

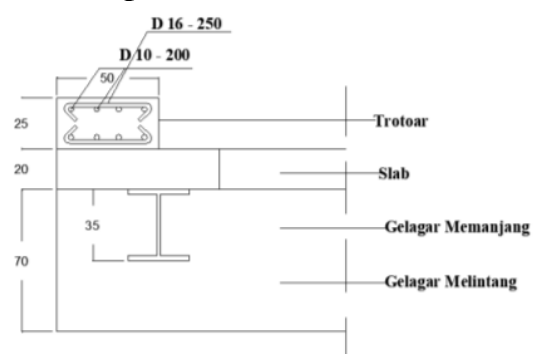

Gambar 15 Pembesian Trotoar

Jadi dapat disimpulkan bahwa untuk merencanakan trotoar dengan momen ultimit sebesar $5,101 \mathrm{kNm}$, tebal rencana trotoar $250 \mathrm{~mm}$, baja tulangan U-32, dan mutu beton K-300, dibutuhkan dimensi tulangan D 16 dengan jarak $250 \mathrm{~mm}$ dan tulangan bagi D 10 dengan jarak $200 \mathrm{~mm}$.

Dalam (Ahmadi, Fahrul 2020) dimensi lebar trotoar direncanakan lebih besar yaitu $0,75 \mathrm{~m}$. Diameter tulangan pokok yang digunakan sama yaitu D $16 \mathrm{~mm}$ tetapi jarak pemasangan tulangan lebih kecil yaitu $200 \mathrm{~mm}$. Sedangkan diameter tulangan bagi yang digunakan lebih besar yaitu D $13 \mathrm{~mm}$ dengan jarak pemasangan yang direncanakan juga lebih besar yaitu $400 \mathrm{~mm}$.

E. Perencanaan Railing

Railing direncanakan menggunakan Baja BJ 37 dengan diameter 4 inchi dan tebal 3,2 mm. Beban yang bekerja sesuai dengan PPPJR 1987 tiang sandaran harus menahan beban horizontal sebesar $100 \mathrm{~kg} / \mathrm{m}$.

a. Kontrol Momen

$$
\begin{aligned}
& M \max =\frac{1}{8} \mathrm{q} \times L s^{2}=1646556,935 \mathrm{Nmm} \\
& M n \quad=Z x \times f y
\end{aligned}
$$


Layla Kumala Rizki, Indriyani Puluhulawa / Jurnal Rab Contruction Research 6 (2) (2021)

$$
\begin{aligned}
\varnothing M n & =0,9 \times M n \\
& =5097600 \mathrm{Nmm}
\end{aligned}
$$

$\mathrm{M} \max <\varnothing M n \quad(\mathbf{O K})$

b. Kontrol Lendutan

$$
\begin{aligned}
\delta & =\frac{5 \mathrm{q} \mathrm{L}^{4}}{384 \mathrm{E} \mathrm{I}} \\
& =1,027 \mathrm{~cm} \\
& =\frac{L}{300} \\
\delta_{\text {izin }} & =1,216 \mathrm{~cm} \\
\delta & <\delta_{\text {izin }}
\end{aligned}
$$

(OK)

Dari hasil perhitungan diperoleh bahwa momen dan lendutan yang terjadi lebih kecil dari yang diizinkan. Jadi dapat disimpulkan bahwa railing BJ 37 dengan diameter 4 inchi dan tebal 3,2 $\mathrm{mm}$ aman digunakan.

Dalam (Fahrudin, Alif 2021) jembatan direncanakan dengan panjang 180 meter dalam 3 bentang dan panjang per segmen adalah 5 meter, diameter dalam railing yang digunakan adalah 3,5 inchi dan dimeter luar yang sama yaitu 101,6 mm. Tetapi tegangan leleh, ketebalan dan berat railing yang digunakan lebih besar yaitu fy $390 \mathrm{MPa}$, tebal 4,2 mm dan berat 10,09 $\mathrm{kg} / \mathrm{m}$.

F. Perencanaan Gelagar Melintang dan Gelagar Memanjang Komposit

Gelagar melintang direncanakan menggunakan profil IWF 700.300.13.24 BJ 55 yang dipasang setiap jarak 5,2 m.

1. Analisa Pembebanan Gelagar Melintang

Hasil perhitungan dari beban-beban yang bekerja pada gelagar melintang jembatan:

a) Beban sebelum aksi komposit

$\mathrm{Q}_{\mathrm{MS}}=30,478 \mathrm{kN} / \mathrm{m}$ dan $\mathrm{Q}_{\mathrm{L}}=2 \mathrm{kN} / \mathrm{m}$

b) Beban setelah aksi komposit

$\mathrm{Q}_{\mathrm{MS} \mathrm{baja}}=2,728 \mathrm{kN} / \mathrm{m}, \mathrm{Q}_{\mathrm{MS} \mathrm{beton}}=26 \mathrm{kN} / \mathrm{m}, \mathrm{Q}_{\mathrm{MA}}=14,448 \mathrm{kN} / \mathrm{m}, \mathrm{Q}_{\mathrm{TD}}=36,9 \mathrm{Kn} / \mathrm{m}, \mathrm{P}_{\mathrm{TD}}=$ $355,446 \mathrm{kN}, \mathrm{Q}_{\mathrm{Ew}_{\mathrm{s}}}=6,6 \mathrm{kN} / \mathrm{m}, \mathrm{P}_{\mathrm{Ew}_{\mathrm{l}}}=3,650 \mathrm{kN}, \Delta \mathrm{T}=12,5{ }^{\circ} \mathrm{C}$

2. Perhitungan Momen Gelagar Melintang

Setelah diperoleh nilai setiap beban pada gelagar melintang, kemudian dilakukan perhitungan momen dan geser sehingga diperoleh hasil seperti pada Tabel 8 berikut:

Tabel 8 Momen dan Geser pada Gelagar Melintang

\begin{tabular}{c|l|c|c|c}
\hline No & \multicolumn{1}{|c|}{ Jenis Beban } & Simbol & $\mathrm{Mu}$ & $\mathrm{Vu}$ \\
\hline \multirow{2}{*}{1} & Berat sendiri beton & MS & 159,250 & 91,000 \\
\cline { 2 - 5 } & Berat sendiri baja & MS & 16,710 & 9,549 \\
\hline 2 & Beban mati tambahan & MA & 65,196 & 43,464 \\
\hline 3 & Beban lajur & TD & 699,219 & 288,423 \\
\hline 4 & Bebang angin struktur & Ews & 40,425 & 23,100 \\
\hline 5 & Beban angin kend & Ewl & 6,388 & 1,825 \\
\hline 6 & Gaya rem & TB & 1,278 & 4,015 \\
\hline
\end{tabular}

Hasil momen dan geser yang diperoleh dihitung dengan mengacu faktor kombinasi beban yang terdapat dalam SNI 1725:2016 sehingga diperoleh nilai momen ultimit sebesar $1616,692 \mathrm{kNm}$ dan geser maksimum sebesar $742,121 \mathrm{kN}$.

3. Perencanaan Penampang Komposit

$\mathrm{L} / 5=1400 \mathrm{~mm}, \mathrm{~S}=5200 \mathrm{~mm}, 12 \mathrm{ts}=2400 \mathrm{~mm}$, maka diambil lebar efektif Be $=1400 \mathrm{~mm}$

Rasio perbandingan modulus elastisitas $\mathrm{n}=\frac{\mathrm{E}_{\mathrm{s}}}{\mathrm{E}_{\mathrm{c}}}=7,895$

Tabel 9 Parameter Penampang Komposit

\begin{tabular}{c|c|c|c|c|c|c}
\hline Bahan & A $(\mathrm{cm} 2)$ & y $(\mathrm{cm})$ & Ay $(\mathrm{cm} 3)$ & Io $(\mathrm{cm} 4)$ & Y-y & $\begin{array}{c}\text { Io }+\mathrm{A}(\mathrm{Y}- \\
\mathrm{y})^{\wedge} 2\end{array}$ \\
\hline
\end{tabular}


Layla Kumala Rizki, Indriyani Puluhulawa / Jurnal Rab Contruction Research 6 (2) (2021)

\begin{tabular}{|c|c|c|c|c|c|c|}
\hline Beton Eq & 354,649 & 10 & 3546,49 & 11821,64 & 17,957 & 126183,758 \\
\hline Baja & 235,500 & 55 & 12952,50 & 201000 & 27,043 & 373222,64 \\
\hline Jumlah & 590,149 & & 16498,992 & 212821,639 & & 499406,399 \\
\hline \multicolumn{7}{|c|}{$\begin{array}{ll}\mathrm{C}=0,85 \mathrm{f}^{\prime} \mathrm{c} \mathrm{Be} \text { ts } & =6913900 \mathrm{~N} \\
\mathrm{~T}=\text { As. Fy } & =9655500 \mathrm{~N}\end{array}$} \\
\hline $\mathrm{C}<$ & \multicolumn{6}{|c|}{$\mathrm{T}$ maka, maka garis netral plastis dalam plat baja } \\
\hline$y=\frac{T-C}{b_{f} f y}$ & $\leq \quad t_{\mathrm{s}}$ & \multicolumn{2}{|c|}{$=22,289 \mathrm{~mm} \leq$} & \multicolumn{2}{|l|}{$200 \mathrm{~mm}$} & \\
\hline \multicolumn{7}{|c|}{$C_{\mathrm{sm}}=2$ fy $\mathrm{y}=18277,333 \mathrm{~N}$} \\
\hline \multicolumn{7}{|c|}{$M n=M p=C\left(Y_{2}+\frac{1}{2} d\right)+C_{\mathrm{sm}}(d-y)^{1 / 2}$} \\
\hline
\end{tabular}

4. Kontrol Aman

a) Kontrol Momen

$\mathrm{Mu} \quad=1616,692 \mathrm{kNm}$

$\varnothing \mathrm{Mn} \quad=2553,814 \mathrm{kNm}$

$\mathrm{Mu} \leq \varnothing \mathrm{Mn}(\mathbf{O K})$

b) Kontrol Geser

$\mathrm{Vu} \quad=742,121 \mathrm{kN}$

$\varnothing \mathrm{Vn} \quad=\varnothing \mathrm{fy} . \mathrm{Aw}=1343,160 \mathrm{kN}$

$\mathrm{Vu} \leq \varnothing \mathrm{Vn}(\mathbf{O K})$

c) Kontrol Lendutan

$\delta$ izin $\quad=\frac{\mathrm{L}}{800}=8,750 \mathrm{~mm}$

$\delta$ kons $=\left(\frac{5}{384} \times \frac{\mathrm{q} \mathrm{B}^{4}}{\mathrm{E}_{\mathrm{x}}}\right)=2,692 \mathrm{~mm}$

$\delta$ kons $\leq \delta$ izin $(\mathbf{O K})$

$\delta_{\mathrm{BTR}+\mathrm{BGT}}=\left(\frac{5}{384} \times \frac{\mathrm{q} \mathrm{B}^{4}}{\mathrm{EI}_{\mathrm{com}}}\right)+\left(\frac{1}{48} \times \frac{\mathrm{pB}^{3}}{\mathrm{E} \mathrm{I}_{\mathrm{com}}}\right)=0,370 \mathrm{~mm}$

$\delta_{\mathrm{BTR}+\mathrm{BGT}} \leq \delta$ izin $(\mathbf{O K})$

5. Perencanaan Stud Connector

Untuk menahan geser yang terjadi akibat aksi komposit antara slab dan baja digunakan stud connector dengan diameter $25 \mathrm{~mm}$, tinggi $125 \mathrm{~mm}$, fu $550 \mathrm{MPa}$, fy $410 \mathrm{MPa}$, luas stud 490,874 mm $2, \mathrm{Vh}=\mathrm{Cc}=6913900 \mathrm{~N}$ dan kuat geser 1 buah stud $\mathrm{Qn}=210546,698 \mathrm{~N}$. Jumlah stud connector yang dibutuhkan:

$\mathrm{N}=\frac{\mathrm{Vh}}{\mathrm{Q}_{\mathrm{n}}}=32,838$ buah $\approx 34$ buah

Diperoleh jumlah stud yang diperlukan untuk 1/2 panjang gelagar melintang adalah 34 buah. Digunakan 68 buah untuk sepanjang gelagar melintang.

Persyaratan jarak antar stud connector:

Jarak minimum longitudinal $6 \varnothing=150 \mathrm{~mm}$

Jarak maksimumlongitudinal $\quad 8 \varnothing \quad=200 \mathrm{~mm}$

Jarak minimum transversal $\quad 4 \varnothing \quad=100 \mathrm{~mm}$

Jika satu buah stud dipasang tiap penampang melintang. Jarak longitudinal untuk 1 bentang antar stud adalah:

$\mathrm{S}=\frac{\mathrm{L}}{2 \mathrm{~N}}=20,59 \mathrm{~cm} \approx 20 \mathrm{~cm}$ 


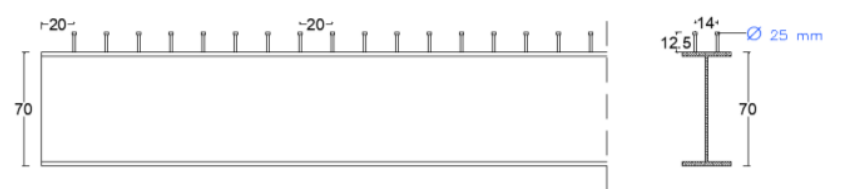

Gambar 16 Pemasangan Stud Connector pada Gelagar Melintang

Berdasarkan perhitungan maka dapat disimpulkan dengan nilai momen dan geser maksimum berturut-turut sebesar 1616,692 kNm dan 742,121 kN, baja profil IWF 700.300.13 24 aman digunakan sebagai gelagar melintang jembatan serta dipasang shear connectror berdiameter $25 \mathrm{~mm}$ dengan tegangan leleh $410 \mathrm{MPa}$ sebanyak 68 buah yang dipasang dalam dua baris dengan jarak $20 \mathrm{~cm}$. Dalam (Kusuma, Arif Tri 2020) nilai momen dan geser maksimum yang diperoleh lebih besar yaitu $1817,9 \mathrm{kNm}$ dan $798,8 \mathrm{kN}$. Profil yang digunakan sebagai gelagar melintang lebih besar yaitu IWF 950.250.16 36 dengan mutu ASTM grade 50.

G. Perencanaan Gelagar Memanjang

Dengan proses yang sama direncanakan gelagar memanjang menggunakan profil IWF 350.175.7.11 BJ 55 yang dipasang setiap jarak 1,5 m. Sehingga diperoleh momen nominal sebesar $M n=M p=$ fy As $\left(\mathrm{Y}_{2}+1 / 2 \mathrm{~d}\right)=840,296 \mathrm{kNm}$.

1. Kontrol Aman

a) Kontrol Momen

$$
\begin{array}{ll}
\mathrm{Mu} & =375,719 \mathrm{kNm} \\
\emptyset \mathrm{Mn} & =756,267 \mathrm{kNm} \\
\mathrm{Mu} \leq \emptyset \mathrm{Mn}(\mathbf{O K})
\end{array}
$$

b) Kontrol Geser

$$
\begin{array}{ll}
\mathrm{Vu} & =193,754 \mathrm{kN} \\
\varnothing \mathrm{Vn} & =\varnothing \mathrm{fy} . \mathrm{Aw}=361,62 \mathrm{kN}
\end{array}
$$

$\mathrm{Vu} \leq \varnothing \mathrm{Vn}(\mathbf{O K})$

c) Kontrol Lendutan

$$
\begin{aligned}
& \delta \text { izin } \quad=\frac{\mathrm{L}}{800}=6,5 \mathrm{~mm} \\
& \delta \text { kons } \quad=\left(\frac{5}{384} \times \frac{\mathrm{q} \mathrm{B}^{4}}{\mathrm{E} \mathrm{I}_{\mathrm{x}}}\right)=4,150 \mathrm{~mm} \\
& \delta \text { kons } \leq \delta \text { izin }(\mathbf{O K}) \\
& \delta_{\text {BTR+BGT }}=\left(\frac{5}{384} \times \frac{\mathrm{q} \mathrm{B}^{4}}{\mathrm{E}_{\text {com }}}\right)+\left(\frac{1}{48} \times \frac{\mathrm{pB}^{3}}{\mathrm{E}_{\text {com }}}\right)=0,330 \mathrm{~mm} \\
& \delta_{\text {BTR+BGT }} \leq \delta \text { izin }(\mathbf{O K})
\end{aligned}
$$

\section{Perencanaan Stud Connector}

Untuk menahan geser yang terjadi akibat aksi komposit antara slab dan baja digunakan stud connector dengan diameter $25 \mathrm{~mm}$, tinggi $125 \mathrm{~mm}$, fu $550 \mathrm{MPa}$, fy $410 \mathrm{MPa}$, luas stud $490,874 \mathrm{~mm}^{2}, \mathrm{Vh}=\mathrm{Cc}=5136040 \mathrm{~N}$ dan kuat geser 1 buah stud $\mathrm{Qn}=210546,698 \mathrm{~N}$. Jumlah stud connector yang dibutuhkan:

$\mathrm{N}=\frac{\mathrm{Vh}}{\mathrm{Q}_{\mathrm{n}}}=12,295$ buah $\approx 25$ buah (menyesuaikan dengan persyaratan jarak pemasangan)

Diperoleh jumlah stud yang diperlukan untuk $1 / 2$ panjang gelagar melintang adalah 25 buah. Digunakan 50 buah untuk sepanjang gelagar melintang.

Persyaratan jarak antar stud connector:

Jarak minimum longitudinal $6 \varnothing=150 \mathrm{~mm}$

Jarak maksimumlongitudinal $\quad 8 \varnothing \quad=200 \mathrm{~mm}$

Jarak minimum transversal $\quad 4 \varnothing \quad=100 \mathrm{~mm}$

Jarak longitudinal untuk 1 bentang antar stud adalah:

$\mathrm{S}=\frac{\mathrm{L}}{2 \mathrm{~N}}=20,8 \mathrm{~cm} \approx 20 \mathrm{~cm}$ 

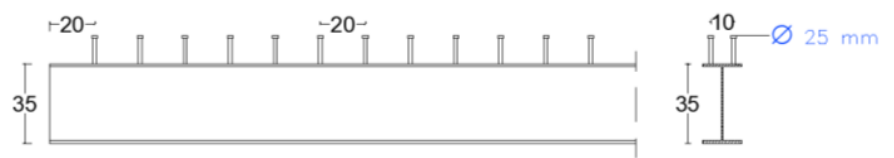

Gambar 17 Pemasangan Stud Connector pada Gelagar Memanjang

Berdasarkan perhitungan maka dapat disimpulkan dengan nilai momen dan geser maksimum berturut-turut sebesar 375,719 kNm dan 193,754 kN, baja profil IWF 350.175.7.11 amandigunakan sebagai gelagar memanjang jembatan serta dipasang shear connectror berdiameter $25 \mathrm{~mm}$ dengan tegangan leleh $410 \mathrm{MPa}$ sebanyak 50 buah yang dipasang dalam dua baris dengan jarak $20 \mathrm{~cm}$.

Dalam (Kusuma, Arif Tri 2020) diperoleh nilai momen dan geser maksimum yang lebih kecil yaitu 242,20 kNm dan $127 \mathrm{kN}$, profil gelagar memanjang yang digunakan lebih besar yaitu IWF 400.200.6 12 dengan mutu ASTM grade 50.

\section{H. Perencanaan Batang Tekan}

Gaya aksial tekan maksimum pada batang atas rangka yang diperoleh dari analisis SAP 2000 adalah sebesar $\mathrm{N}_{\mathrm{u}}=5376,103 \mathrm{kN}$.

Berdasarkan hasil perhitungan dioperoleh $\lambda_{\mathrm{cx}}=0,365$ dan $\lambda_{\mathrm{cy}}=0,629$

Periksa kekompakan penampang terhadap sumbu $\mathrm{x}$

$\lambda_{c}=0,365<1,5$

$$
\begin{aligned}
\emptyset N_{n}=\emptyset\left(0,66 \lambda_{c}^{2}\right) A_{g} f y & =7211,166 \mathrm{kN} \\
\frac{\mathrm{N}_{\mathrm{u}}}{\emptyset \mathrm{N}_{\mathrm{n}}} & =0,746<\quad 1
\end{aligned}
$$

(OK)

Periksa kekompakan penampang terhadap sumbu y

$\lambda_{c}=0,629<1,5$

$\emptyset N_{n}=\varnothing\left(0,66 \lambda_{c}^{2}\right) A_{g} f y=6464,834 \mathrm{kN}$

$\frac{\mathrm{N}_{\mathrm{u}}}{\emptyset \mathrm{N}_{\mathrm{n}}} \quad=0,832<\quad 1 \quad(\mathbf{O K})$

Dengan langkah perhitungan yang sama dilakukan perencanaan batang tekan pada diagonal rangka utama dan ikatan angin. Hasil yang diperoleh dari perhitungan yaitu digunakan profil IWF 400.400.13.21 untuk batang tekan diagonal rangka utama dan

\begin{tabular}{|c|c|c|c|c|c|c|c|c|}
\hline No & Batang & \multicolumn{2}{|c|}{ Gaya Tekan } & Profil Rencana & Kelangsingan & Flens & Web & Kekuatan \\
\hline 1 & $\begin{array}{l}\text { Batang atas } \\
\text { rangka utama }\end{array}$ & 5376,103 & $\mathrm{kN}$ & $\begin{array}{c}\text { IWF } \\
400.400 .13 .21\end{array}$ & $\lambda<140$ & $\begin{array}{l}\lambda< \\
\lambda \mathrm{p}\end{array}$ & $\begin{array}{l}\lambda< \\
\lambda \mathrm{p}\end{array}$ & $\frac{\mathrm{Nu}}{\emptyset \mathrm{Nn}}<1$ \\
\hline 2 & $\begin{array}{c}\text { Batang } \\
\text { diagonal } \\
\text { rangka utama }\end{array}$ & 2426,308 & $\mathrm{kN}$ & $\begin{array}{c}\text { IWF } \\
400.400 .13 .21\end{array}$ & $\lambda<140$ & $\begin{array}{l}\lambda< \\
\lambda p\end{array}$ & $\begin{array}{l}\lambda< \\
\lambda \mathrm{p}\end{array}$ & $\frac{\mathrm{Nu}}{\emptyset \mathrm{Nn}}<1$ \\
\hline 3 & Ikatan angin & 27,577 & $\mathrm{kN}$ & $\begin{array}{c}\text { IWF } \\
150.150 .7 .10\end{array}$ & $\lambda<140$ & $\begin{array}{l}\lambda< \\
\lambda p\end{array}$ & $\begin{array}{l}\lambda< \\
\lambda \mathrm{p}\end{array}$ & $\frac{\mathrm{Nu}}{\emptyset \mathrm{Nn}}<1$ \\
\hline & & Kontrol & & & OK & OK & OK & OK \\
\hline
\end{tabular}
digunakan profil IWF 200.200.8.12 untuk batang tekan pada ikatan angin.

Tabel 10 Perencanaan Batang Tekan

I. Perencanaan Batang Tarik

Berdasarkan hasil analisis dari SAP 2000 diperoleh gaya aksial tarik maksimum pada batang bawah gelagar utama sebesar $\mathrm{P}_{\mathrm{u}}=1849,575 \mathrm{kN}$.

1. Periksa kekuatan penampang terhadap leleh

$$
\emptyset \mathrm{P}_{\mathrm{n}}=\varnothing \mathrm{A}_{\mathrm{g}} \times \mathrm{fy}=8079,03 \mathrm{kN}
$$


Layla Kumala Rizki, Indriyani Puluhulawa / Jurnal Rab Contruction Research 6 (2) (2021)

$\frac{\mathrm{Pu}}{\emptyset \mathrm{P}_{\mathrm{n}}} \quad=0,229<1 \quad(\mathbf{O K})$

2. Periksa kekuatan penampang terhadap fraktur

$\mathrm{U}=0,9$

Luas netto penampang $\left(A_{n}\right)$

$A_{n}=A_{g}-n \underset{\times}{d} t=20526 m^{2}$

$85 \% \mathrm{~A}_{\mathrm{g}}=18589,5 \mathrm{~mm}^{2}$

Luas netto yang digunakan adalah nilai yang terkecil yaitu $18589,5 \mathrm{~mm}^{2}$

$$
\begin{aligned}
& A_{\mathrm{e}} \quad=\mathrm{U} \times \mathrm{A}_{\mathrm{n}}=16730,55 \mathrm{~mm}^{2} \\
& \varnothing \mathrm{P}_{\mathrm{n}}=\emptyset \mathrm{A}_{\mathrm{e}} \times \mathrm{fu}=6901,352 \mathrm{kN} \\
& \frac{\mathrm{Pu}}{\emptyset \mathrm{P}_{\mathrm{n}}}
\end{aligned}
$$

Dengan langkah perhitungan yang sama dilakukan perencanaan batang tarik pada diagonal rangka utama dan ikatan angin. Hasil yang diperoleh dari perhitungan yaitu digunakan profil IWF 400.400.13.21 untuk batang tarik diagonal rangka utama dan digunakan profil IWF 150.150.7.10 untuk batang tarik pada ikatan angin.

Tabel 11 Perencanaan Batang Tarik

\begin{tabular}{c|l|c|c|c|c|c}
\hline No & Batang Tarik & \multicolumn{2}{|c|}{ Gaya Tarik } & Profil Rencana & Leleh & Fraktur \\
\hline 1 & $\begin{array}{l}\text { Batang bawah } \\
\text { rangka utama }\end{array}$ & 1848,575 & $\mathrm{kN}$ & IWF 400.400.13.21 & $\frac{\mathrm{Pu}}{\emptyset \mathrm{Pn}}<1$ & $\frac{\mathrm{Pu}}{\emptyset \mathrm{Pn}}$ \\
\hline 2 & $\begin{array}{l}\text { Batang } \\
\text { diagonal rangka } \\
\text { utama }\end{array}$ & 2304,832 & $\mathrm{kN}$ & IWF 400.400.13.21 & $\frac{\mathrm{Pu}}{\emptyset \mathrm{Pn}} 1$ & $\frac{\mathrm{Pu}}{\emptyset \mathrm{Pn}}$ \\
\hline 3 & Ikatan angin & 10,491 & $\mathrm{kN}$ & IWF 150.150.7.10 & $\frac{\mathrm{Pu}}{\emptyset \mathrm{Pn}}$ & $\frac{\mathrm{Pu}}{\emptyset \mathrm{Pn}}$ \\
\hline
\end{tabular}

Berdasarkan perhitungan dapat disimpulkan bahwa profil IWF 400.400.13.21 aman digunakan untuk menahan gaya aksial tekan dan tarik maksimum yang terjadi pada batang atas rangka utama, batang diagonal, batang bawah rangka utama. Sedangkan sebagai ikatan angin direncanakan ikatan angin berbentuk $X$ dengan baja profil IWF 150.150.7.10 untuk menahan gaya aksial tekan dan tarik maksimum yang terjadi.

J. Perencanaan Sambungan

Sambungan pada jembatan direncanakan menggunakan baut tipe A325 dengan fub $=825$ MPa. Untuk sambungan rangka utama serta sambungan antara gelagar melintang dan gelagar memanjang digunakan baut dengan diameter $30 \mathrm{~mm}$ dan plat buhul dengan tebal $18 \mathrm{~mm}$. Sedangkan untuk sambungan pada ikatan angin digunakan baut dengan diameter $20 \mathrm{~mm}$ dan plat buhul dengan tebal $18 \mathrm{~mm}$.

K. Perencanaan Perletakan

Berdasarkan hasil perhitungan diperoleh kuat geser ultimit yang terjadi sebesar 76,484 ton. Maka dibutuhkan Elastomer Bearing yang diperlukan adalah 250 . 330 dengan Tebal $10 \mathrm{~mm}$ dan 5 Lapisan. 
L. Gambar Hasil Perencanaan

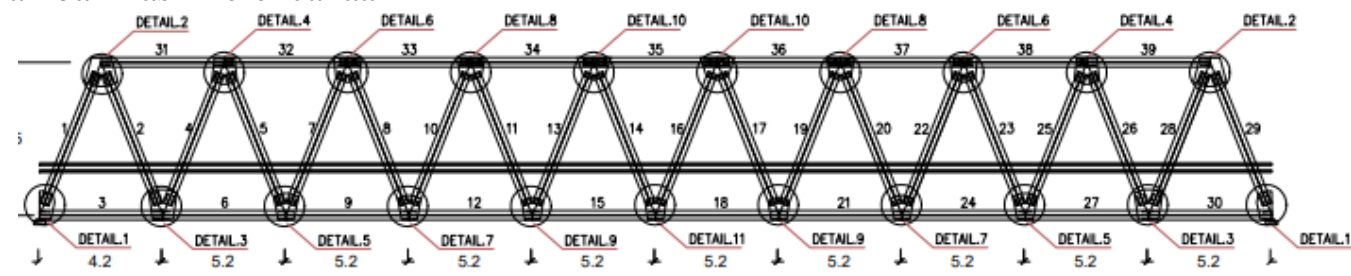

Gambar 18 Tampak Samping Jembatan

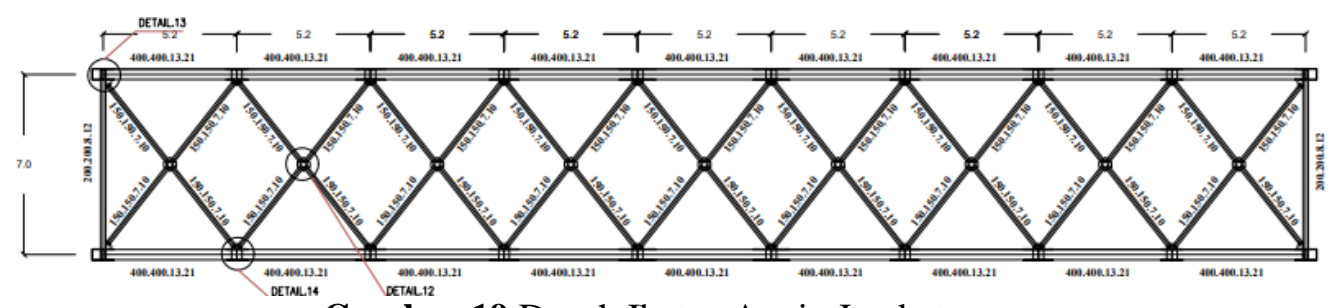

Gambar 19 Denah Ikatan Angin Jembatan

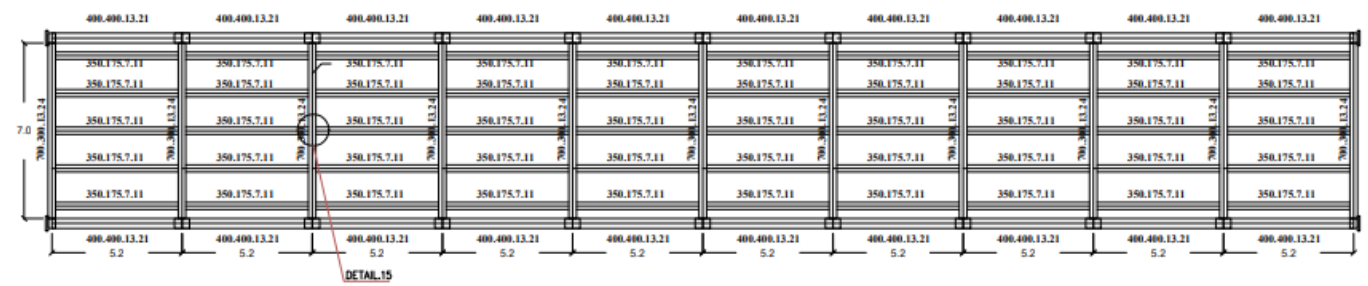

Gambar 20 Denah Gelagar Jembatan

\section{SIMPULAN}

Adapun beberapa kesimpulan yang dapat ditarik setelah dilakukannya penelitian yaitu:

a. Jembatan Sungai Mesim direncanakan sepanjang $52 \mathrm{~m}$ dan lebar $7 \mathrm{~m}$.

b. Tebal slab jembatan yang direncanakan adalah $200 \mathrm{~mm}$

c. Tebal trotoar yang direncanakan adalah $250 \mathrm{~mm}$

d. Railing direncanakan dengan diameter $101,6 \mathrm{~mm}$

e. Gelagar melintang direncanakan menggunakan profil IWF 700.300.13.24, gelagar memanjang direncanakan menggunkan profil IWF 350.175.7.11, rangka utama direncanakan menggunakan profil IWF 400.400.13.21 dan ikatan angin direncanakan menggunakan profil IWF 150.150.7.10

f. Sambungan direncanakan menggunakan baut A325 dengan diameter $30 \mathrm{~mm}$ dan $20 \mathrm{~mm}$

g. Perletakan direncanakan menggunakan elastomer bearing ukuran $250.300 \mathrm{~mm}$ dengan tebal $10 \mathrm{~mm}$ sebanyak 5 lapisan.

\section{UCAPAN TERIMA KASIH}

Terimakasih penulis haturkan kepada dosen pembimbing yang telah memberikan bimbingan, arahan serta tunjuk ajar kepada penulis sehingga penulis dapat menyelesaikan penelitian ini. Terimakasih juga penulis ucapkan kepada tim Jurnal RAB Construction Research Universitas Abdurrab yang telah menyusun template jurnal ini sehingga penulis dapat menyusun jurnal sesuai dengan sistematika penulisan.

\section{DAFTAR PUSTAKA}

Ahmadi, Fahtul. 2020. Desain Jembatan Jalan Datuk Laksmana Dengan T-Girder Menggunakan SNI 1725-2016. Bengkalis: Jurusan Teknik Sipil.

Badan Standarisasi Nasional. 2016. Perencanaan Pembebanan Jembatan SNI 1725:2016. Jakarta. 
Layla Kumala Rizki, Indriyani Puluhulawa / Jurnal Rab Contruction Research 6 (2) (2021)

Badan Standarisasi Nasional. 2004. Perencanaan Struktur Beton SNI T 12-2004. Jakarta.

Badan Standarisasi Nasional. 2005. Perencanaan Struktur Baja Untuk Jembatan. SNI T 032005. Jakarta.

Dewobroto, Wiryanto. 2016. Struktur Baja Perilaku, Analisis \& Desain - AISC 2010. Tangerang: Universitas Pelita Harapan.

Fahrudin, Kharis Arif. 2021. Perencanaan Jembatan Tanggulangin Pada Ruas Jalan DemakKudus Dengan Sistem Rangka Baja. Surakarta: Universitas Muhammadiyah Surakarta.

Kusuma, Arif Tri. 2020 . Perencanaan Struktur Jembatan Rangka Baja Bentang 60 Meter Dengan Kelas A Type Warren Truss. Jakarta Barat: Universitas Gunadarma.

Wahyu, Hasneti. 2018. Perencanaan Struktur Atas Jembatan Sungai Sair Dengan Struktur Rangka Baja. Bengkalis: Politeknik Negeri Bengkalis. 